\title{
Prevalence of asthma among Middle Eastern children: A systematic review
}

\author{
Masoud Mirzaei ${ }^{1}$, Mehran Karimi², Shima Beheshti ${ }^{3}$, Masoud Mohammadi*4
}

\begin{abstract}
Background: The prevalence of asthma and allergy has increased during the last decades, especially in children. However, little is known about it in the Middle East region. This systematic review is aimed to estimate the prevalence of asthma among the Middle Eastern children.

Methods: Local and international scientific databases including SID, Iranmedex, Medline and Science Direct were systematically searched for relevant keywords including; asthma, prevalence, children, International Study of Asthma and Allergies in Childhood (ISACC) and the names of Middle Eastern countries for the period of 1996-2011. Papers in Persian and English which met the defined criteria were included into the study. Bibliographies of the extracted articles were also searched. After extraction of data, heterogeneity between studies and publication bias were measured using Egger's-test. Effect size was pooled by the random-effect model. Since significant heterogeneity was found between studies, univariate meta-regression analyses were done to assess the association of variables with the overall results.

Results: Fifty studies in the Middle East examined the prevalence of asthma and allergy in children under the age of 18 years according to the ISAAC criteria and were included. A total number of 289,717 children were examined in the included studies and the prevalence varied from $0.7 \%$ in Isfahan to $22.3 \%$ in Bagdad. The total prevalence of diagnosed asthma was calculated $7.53 \%(95 \% \mathrm{Cl}$ : $6.38-8.75)$. Prevalence of asthma in the $13-14$ years age group was $7.57 \%(95 \% \mathrm{Cl}: 5.78-9.29)$ and in $6-7$ years age group was $7.43 \%$ (95\% Cl: 5.75-9.10). The prevalence of asthma among girls, based on random effect model, was $6.30 \%(95 \% \mathrm{Cl}: 4.97-7.61)$ and among boys, it was $8.91 \%$ (95\% Cl: $6.80-11.04)$.

Conclusion: The prevalence of asthma in the Middle East is lower than most developed countries. However, there is not enough longitudinal data to estimate the trend over time. In order to have more accurate estimates and to provide evidence for proper planning, standard epidemiologic studies should be conducted in countries of the region.
\end{abstract}

Keywords: Asthma, Prevalence, Middle East, Children, Systematic review

Copyright $@$ Iran University of Medical Sciences

Cite this article as: Mirzaei M, Karimi M, Beheshti Sh, Mohammadi M. Prevalence of asthma among Middle Eastern children: A systematic review. Med J Islam Repub Iran. 2017(12 Feb);31:9. https://doi.org/10.18869/mjiri.31.9

\section{Introduction}

Worldwide, the prevalence of asthma has increased during the last three decades $(1,2)$. According to the World Health Organization estimate in 2005, around 300 million people were affected by asthma. According to the existing evidence, the prevalence of asthma and allergy in children is increasing around the world (3). It is estimated that this number will reach 400 millions by 2025 .

\footnotetext{
Corresponding author: Masoud Mohammadi, masoud.mohammadi1989@yahoo.com

1. Yazd Cardiovascular Research Centre, Shahid Sadoughi University of Medical Sciences, Yazd, Iran.

2. Department of Pediatrics, Shahid Sadoughi University of Medical Sciences, Yazd, Iran.

3. Hormozgan University of Medical Sciences, Bandar Abbas, Iran.

4. Department of Social Medicine, Faculty of Medicine, Kermanshah University of Medical Sciences, Kermanshah, Iran.
}

In some industrialized countries the prevalence of asthma and allergy has reached to a warning level, and has affected more than one-third of the children (4). It is not clear that this increase is due to a real increase in the prevalence of asthma and allergy (5), or it is due to a higher level of awareness and diagnosis. According to some studies, in developed countries the prevalence of asthma has stopped to in-

$\uparrow$ What is "already known" in this topic:

Prevalence of asthma and allergy has reached to more than one-third of the children in some developed countries. It seems that factors like age, sex, economic status, genetics and exposure to indoor and outdoor pollutions are related to the prevalence of asthma.

\section{$\rightarrow$ What this article adds:}

The prevalence of asthma in the Middle Eastern countries is lower than most developed countries. The prevalence studies of asthma in the Middle East have to be repeated every 5 years using criteria such as that of ISACC to reflect the trends of the changes over time. 
crease or even started to decrease in the recent years (6- 8). It seems that factors like age, sex, economic status, genetics and exposure to indoor and outdoor pollutions are related to the prevalence of asthma $(9,10)$.

In a study by Smith Kline et al. in 2002, around one-third of those who were affected by asthma had some limitations in doing their daily activities such as physical exercise, social activities and sleeping (11).

Overall, respiratory diseases cause $6.3 \%$ of the total death around the world, and the share of asthma is $0.4 \%$ (12). Based on the National Statistical Office of Korea, the mortality rate, due to chronic respiratory diseases (including asthma) increased during 1992 to 2002 from 12.9 to 22.6 per 100,000 population. In 1992 chronic diseases of the lower respiratory system was the eighth cause of death in Korea, and it reached to the fifth cause in 2002 (13).

Children's asthma is a main clinical concern around the world that imposes a great burden on families and the society. The disease can impede the academic development and social activities of the children. Children's asthma is a burden on the health care system due to successive referral to practitioner and hospital which costs a lot $(14,15)$. Due to the lack of a standard method for asthma diagnosis, examining the prevalence of asthma over time (16) was difficult. The International Study of Asthma and Allergies in Children (ISAAC) was established in 1991 in order to provide reliable data on the prevalence of the disease, its symptoms and changes during the time and in different countries. In the first phase children in the age group of 13-14 years in 56 countries, and in the age group of 6 to 7 years in 38 countries were evaluated during 1994 to 1995 . The second phase of ISAAC aimed to investigate risk factors of the disease in 1998; only 22 countries participated, and no Middle Eastern countries were involved. Several Middle Eastern countries took part in various phases of ISAAC. However no systematic review was published from these studies. This study aims to systematically review the prevalence of asthma, according to ISAAC standard method, in the Middle Eastern children.

\section{Methods}

\section{Data}

Iranian scientific databases including Iranmedex and SID, as well as major international databases including Medline and Science Direct were searched to find the relevant papers. The searched keywords were "Asthma", "prevalence", "children", "ISACC" and "Middle East" in English and the Persian equivalents.
"Citation pearl growing" technique (17) was used to search the reference lists of the extracted papers. This cross checking method continued up until no other relevant article was found. In this study, all papers published from 1996-2011, in English or Persian languages, were searched, reviewed and included if they met certain quality criteria. The results of this research were limited to cross- sectional descriptive studies. The research was conducted during September to November 2012.

Summaries of the extracted articles were reviewed first. Initial screening was done based on the subjects and summaries of the articles. If the article was a peer reviewed epidemiologic study and the prevalence of asthma and the asthma symptoms were reported in the article, then the article was considered for quality check and inclusion. If some articles were extracted from one study, the one with the most details was selected. If the full text was not available, authors of the paper were contacted.

Selection criteria for the included papers were; a) population-based studies which reported prevalence of asthma, b) age of the population groups less than 18 years, c) random or census sampling of the study, d) using ISACC methods to diagnose asthma, and e) the article published either in English or Persian.

Studies which had the criteria to be entered into the study were coded in an information summary form, using FileMaker Pro V. 8.0 (FileMaker Inc., Santa Clara, CA -USA). Some of the articles (10\%) were summarized and evaluated by two coders.

Coding form of the studies consisted of four sections including information related to the aim of the study, characteristics of the target population, sampling method, information related to criteria for asthma diagnosis, epidemiologic information in order to extract the data reported in the article and information related to the quality of the study.

The quality of the studies was evaluated using a set of defined criteria. The relevant checklist was designed according to the critical evaluation guideline of research papers on prevalence published by Loney et al. (18). The criteria are about the design including proper sampling framework, adequate sample size, appropriate evaluation of the result and the response rate; interpretation included reporting the prevalence with confidence interval and adequate sub-group analysis and applicability of the results including explanation of the aims and detailed conditions. Quality grading of each study was made by two coders, and the results were compared to ensure inter-coder agreement. In cases of inconsistency between the coders, they discussed the issue until consensus was reached. 


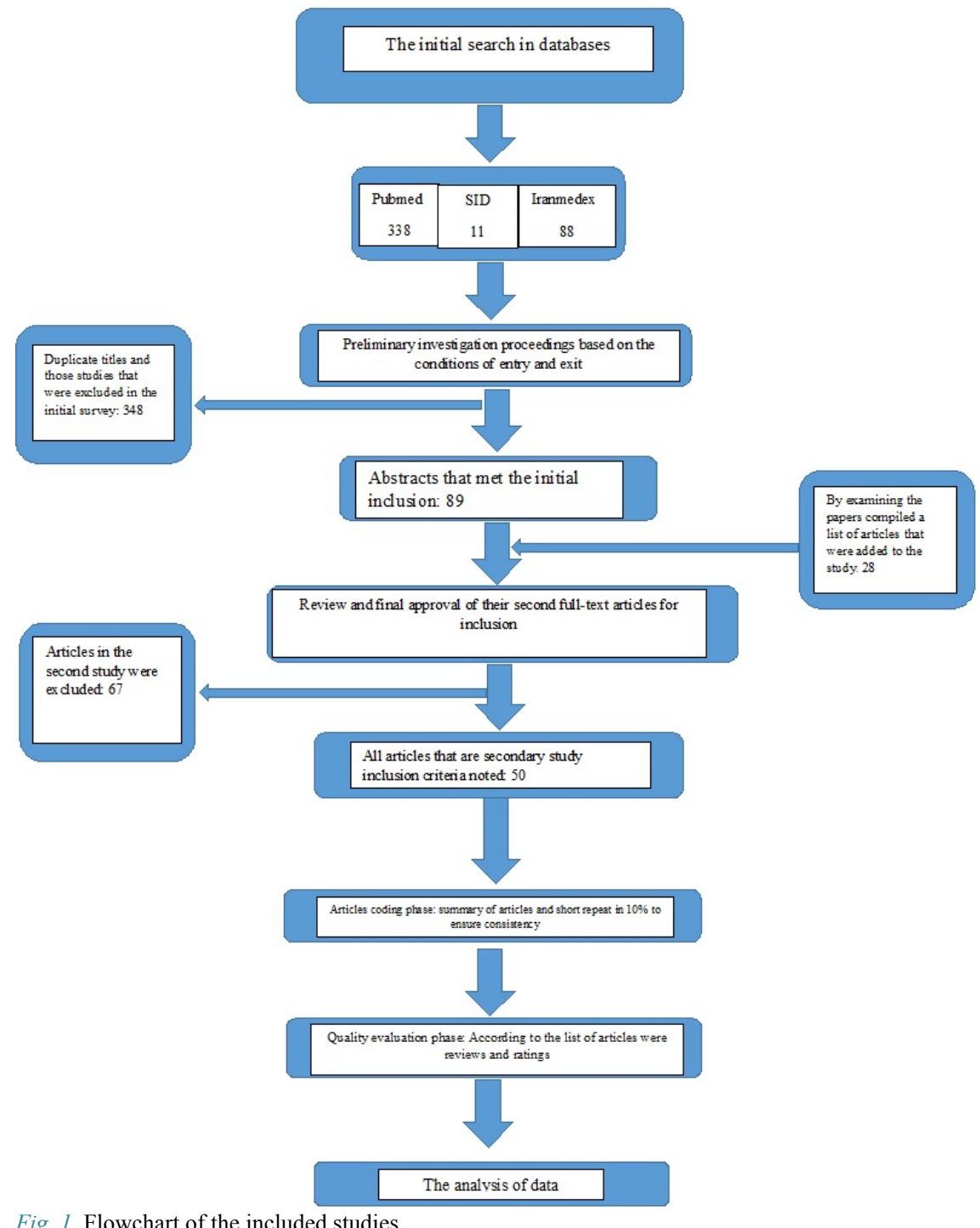

Fig. 1. Flowchart of the included studies

\section{Data analysis}

The first step of data analysis was to estimate overall pooled prevalence of asthma among all studies. To assess heterogeneity, $\mathrm{I}^{2}$ Test was used in order to determine whether the difference between estimated prevalence in different studies is higher than the randomly expected value.

A significant heterogeneity between the included studies was found. Univariate meta-regression analysis was done in order to evaluate the relationship between methodological variables, age, and sex with the total estimate of the prevalence of asthma using meta-regression analysis. This analytical strategy tries to find which variable has affected the total result. Examined methodological variables were sample size, year of publication, quality score of the article, and also per capita income and air pollution of the countries.

In this analysis the relationship between methodological variables like sample size, published year of the study, quality of the included studies, and also the language of the questionnaire, was analyzed to see any relation with the prevalence of asthma.

Due to the existing inconsistency in the studies, a sensitivity analysis was conducted to determine the influence of each included study on the total estimation. There was no significant change observed by excluding any particular paper.

Effect of each variable including methodology, geographic area of the study, urban and rural and population mean age on the prevalence estimate were investigated by meta-regression analysis. This strategy investigates which variable affects the final results. The regressed variables include sample size, publication year, and article's quality score. All statistical analysis was done using STATA SE (Ver.10).

\section{Results}

Out of 814 identified papers in the initial search, after exclusion of repeated publications and critical 
appraisal, 89 articles had the inclusion criteria. After searching bibliography of the papers, 28 more papers were identified, and the total number reached to 117 (Fig. 1).

Out of the 117 articles, 67 articles excluded in the detailed review phase, either because they used nonISAAC protocol and questionnaire, or conducted in a specific age group (19-22), or had ISAAC questionnaire, but their reports were different from ISAAC protocol and thus excluded (23-27). The total number of subjects in the included studies $(\mathrm{N}=50)$ was 289,717 . Five articles (10\% of all articles), had a population more than 10,000 (45.6\% of the total subjects). The majority of the studies $(88 \%)$ had the population between 1000 and 10000 (54\% of all subjects). Only one study had a population less than 1000 (Table 1).
More than half of the studies were done in urban populations, and the rest were done in the urban and rural population at the same time. Only one study was conducted among men, and the rest included both men and women.

Eighteen countries of the Middle East including Iran, Saudi Arabia, Oman, Lebanon, Palestine, Qatar, Kuwait, Bahrain, Iraq, Morocco, Egypt, United Arab Emirates, Syria, Israel and Yemen were included in this systematic review. Twenty-six studies were from Iran (52\%), eight studies were from other Persian Gulf countries $(26 \%)$, six studies $(16 \%)$ were from other Arabic countries of the Middle East and the rest were from North Africa (Table 2).

The majority of studies (52\%) used Persian translation of the ISAAC questionnaire followed by Arabic translation (46\%) and French translation (2\%).

Table 1. Summary of the included studies on prevalence of asthma in children of the Middle East from 1996-2011

\begin{tabular}{|c|c|c|c|c|c|c|c|c|}
\hline Author & year & The study area & Country & $\begin{array}{c}\text { Type of } \\
\text { area }\end{array}$ & $\begin{array}{c}\text { Sample } \\
\text { size }\end{array}$ & $\begin{array}{l}\text { The age } \\
\text { range }\end{array}$ & Sex & $\begin{array}{l}\text { Quality } \\
\text { Score } \\
\end{array}$ \\
\hline El-Sharif N.A. et al (61) & 2003 & Ramallah \& Qaza & Palestine & $\begin{array}{c}\text { Urban / } \\
\text { rural }\end{array}$ & 14355 & 12 years & Girl/Boy & 13 \\
\hline El-Sharif N.A. et al (53) & 2002 & Ramallah & Palestine & $\begin{array}{l}\text { Urban / } \\
\text { rural }\end{array}$ & 3382 & $\begin{array}{l}6 \text { to } 14 \\
\text { years }\end{array}$ & Girl/Boy & 11 \\
\hline Bener A. et al (28) & 2007 & Qatar & Qatar & $\begin{array}{l}\text { Urban / } \\
\text { rural }\end{array}$ & 31400 & $\begin{array}{l}13 \text { to } 19 \\
\text { years }\end{array}$ & Girl/Boy & 6 \\
\hline Janahi I.A. et al (62) & 2006 & Doha & Qatar & $\begin{array}{l}\text { Urban / } \\
\text { rural }\end{array}$ & 3282 & $\begin{array}{l}11 \text { to } 15 \\
\text { years }\end{array}$ & Girl/Boy & 9 \\
\hline Nahhas M. et al (54) & 2012 & Medina & Saudi Arabia & Urban & 5188 & $\begin{array}{l}6 \text { to } 14 \\
\text { years }\end{array}$ & Girl/Boy & 10 \\
\hline Al Ghobain M.O.et al (63) & 2012 & Riyadh & Saudi Arabia & Urban & 3073 & 6 to 7 years & Girl/Boy & 10 \\
\hline Alshehri M.A. et al (64) & 2000 & Abha & Saudi Arabia & Urban & 3274 & $\begin{array}{l}13 \text { to } 14 \\
\text { years }\end{array}$ & Boy & 10 \\
\hline Hijazi N. et al (65) & 1999 & Jeddah & Saudi Arabia & $\begin{array}{c}\text { Urban / } \\
\text { rural }\end{array}$ & 1444 & $\begin{array}{l}7 \text { to } 11 \\
\text { years }\end{array}$ & Girl/Boy & 8 \\
\hline Mohammad Y. et al (66) & 2010 & Aleppo, Lattika, Tartous & $\begin{array}{l}\text { Syrian Arab } \\
\text { Republic }\end{array}$ & Urban & 10214 & 6 to 7 years & Girl/Boy & 12 \\
\hline Alsowaidi S. et al (20) & 2010 & Al-Ain & $\begin{array}{l}\text { United Arab } \\
\text { Emirates }\end{array}$ & Urban & 2802 & 6 to 7 years & Girl/Boy & 9 \\
\hline Georgy V. et al (67) & 2006 & EI Nozha area of Cairo & Egypt & Urban & 2645 & $\begin{array}{l}12 \text { to } 15 \\
\text { years }\end{array}$ & Girl/Boy & 8 \\
\hline Zobeiri M. et al (68) & 2011 & Kermanshah & Iran & $\begin{array}{l}\text { Urban / } \\
\text { rural }\end{array}$ & 6236 & $\begin{array}{l}6 \text { to } 11 \\
\text { years }\end{array}$ & Girl/Boy & 11 \\
\hline Rahimi Rad M.H.et al (69) & 2008 & Urmia & Iran & Urban & 2999 & $\begin{array}{l}6 \text { to } 12 \\
\text { years }\end{array}$ & Girl/Boy & 11 \\
\hline Rahimi Rad M.H. et al (48) & 2007 & Urmia & Iran & Urban & 3000 & $\begin{array}{l}6 \text { to } 14 \\
\text { years }\end{array}$ & Girl/Boy & 12 \\
\hline Kajbaf T.Z. et al (70) & 2011 & Ahvaz & Iran & Urban & 903 & $\begin{array}{c}13 \text { to } 14 \\
\text { years }\end{array}$ & Girl/Boy & 6 \\
\hline Shakurnia A.H. et al (71) & 2010 & Ahvaz & Iran & Urban & 2860 & 5 to 7 years & Girl/Boy & 11 \\
\hline Masjedi M.R. et al (72) & 2004 & Tehran & Iran & Urban & 6140 & $\begin{array}{l}13 \text { to } 14 \\
\text { years }\end{array}$ & Girl/Boy & 10 \\
\hline Golshan M. et al (73) & 2002 & Isfahan & Iran & Urban & 3924 & $\begin{array}{l}5 \text { to } 12 \\
\text { years }\end{array}$ & Girl/Boy & 10 \\
\hline Golshan M. et al (29) & 2001 & Isfahan & Iran & Urban & 3858 & $\begin{array}{l}13 \text { to } 14 \\
\text { years }\end{array}$ & Girl/Boy & 10 \\
\hline AL-Thamiri D. et al (30) & 2005 & Baghdad & Iraq & Urban & 2889 & $\begin{array}{l}13 \text { to } 14 \\
\text { years }\end{array}$ & Girl/Boy & 9 \\
\hline Abu-Ekteish F. et al (74) & 2009 & Amman, Al-Mafraq & Jordan & $\begin{array}{c}\text { Urban / } \\
\text { rural }\end{array}$ & 9108 & $\begin{array}{l}13 \text { to } 14 \\
\text { years }\end{array}$ & Girl/Boy & 12 \\
\hline Owayed A et al (75) & 2008 & Kuwait City & Kuwait & Urban & 2882 & $\begin{array}{l}13 \text { to } 14 \\
\text { years }\end{array}$ & Girl/Boy & 12 \\
\hline Abal A.T. et al (76) & 2010 & Kuwait City & Kuwait & Urban & 2117 & $\begin{array}{l}6 \text { to } 14 \\
\text { years }\end{array}$ & Girl/Boy & 8 \\
\hline Musharrafieh U. et al (77) & 2009 & Beirut & Lebanon & $\begin{array}{l}\text { Urban / } \\
\text { rural }\end{array}$ & 3115 & $\begin{array}{l}13 \text { to } 14 \\
\text { years }\end{array}$ & Girl/Boy & 10 \\
\hline Waked M.et al (20) & 2008 & $\begin{array}{l}\text { Beka, Beirut, Mount, Naba- } \\
\text { tieh, North, South }\end{array}$ & Lebanon & $\begin{array}{l}\text { Urban / } \\
\text { rural }\end{array}$ & 3907 & $\begin{array}{l}13 \text { to } 14 \\
\text { years }\end{array}$ & Girl/Boy & 9 \\
\hline Waked M. et al (78) & 2006 & $\begin{array}{l}\text { Beka, Beirut, Mount, Naba- } \\
\text { tieh, North, South }\end{array}$ & Lebanon & $\begin{array}{l}\text { Urban / } \\
\text { rural }\end{array}$ & 1613 & $\begin{array}{c}13 \text { to } 14 \\
\text { years }\end{array}$ & Girl/Boy & 12 \\
\hline Ait-Khaled N. et al (60) & 2007 & $\begin{array}{c}\text { Wialya of Algeria,Khartoum } \\
\text { of Sudan, Grand Tunis \& } \\
\text { Sousse of Tunisia,... }\end{array}$ & Africa & $\begin{array}{c}\text { Urban / } \\
\text { rural }\end{array}$ & 66335 & $\begin{array}{l}6 \text { to } 14 \\
\text { years }\end{array}$ & Girl/Boy & 10 \\
\hline
\end{tabular}


M. Mirzaei, et al.

\begin{tabular}{|c|c|c|c|c|c|c|c|c|c|}
\hline Bouyad Z.et al (79) & 2006 & \multicolumn{2}{|r|}{$\begin{array}{l}\text { Casabelanca, Marrakech, } \\
\text { BenSlimane, Boulmane }\end{array}$} & Morocco & Urban & 5665 & $\begin{array}{l}6 \text { to } 14 \\
\text { years }\end{array}$ & Girl/Boy & 11 \\
\hline Al-Rawas O.A. et al (58) & 2008 & \multicolumn{2}{|c|}{ Eight geographical regions of Oman } & Oman & $\begin{array}{l}\text { Urban / } \\
\text { rural }\end{array}$ & 7879 & $\begin{array}{l}13 \text { to } 14 \\
\text { years }\end{array}$ & Girl/Boy & 11 \\
\hline Al-Riyami B.M. et al (59) & 2003 & \multicolumn{2}{|r|}{ Sultanate } & Oman & Urban & 3893 & $\begin{array}{c}13 \text { to } 14 \\
\text { years }\end{array}$ & Girl/Boy & 12 \\
\hline Shohat T. et al (56) & 2000 & \multicolumn{2}{|r|}{ Nicosa, Limass } & Israel & $\begin{array}{l}\text { Urban / } \\
\text { rural }\end{array}$ & 10057 & $\begin{array}{l}13 \text { to } 14 \\
\text { years }\end{array}$ & Girl/Boy & 13 \\
\hline Golshan M.et al (73) & 2002 & \multicolumn{2}{|r|}{ Zarinshahr } & Iran & Urban & 1309 & $\begin{array}{l}6 \text { to } 13 \\
\text { years }\end{array}$ & Girl/Boy & 9 \\
\hline $\begin{array}{l}\text { Habibi Khorasani A. et al } \\
(80)\end{array}$ & 1998 & \multicolumn{2}{|r|}{ Kermanshah } & Iran & Urban & 2217 & $\begin{array}{l}6 \text { to } 12 \\
\text { years }\end{array}$ & Girl/Boy & 9 \\
\hline Bazzazi H. et al (81) & 2006 & \multicolumn{2}{|r|}{ Gorgan } & Iran & Urban & 2800 & $\begin{array}{c}12 \text { to } 13 \\
\text { years }\end{array}$ & Girl/Boy & 8 \\
\hline Mohammadzadeh I. et al (82) & 2008 & \multicolumn{2}{|r|}{ Babol } & Iran & Urban & 5933 & $\begin{array}{l}6 \text { to } 14 \\
\text { years }\end{array}$ & Girl/Boy & 12 \\
\hline Hasanzadeh J. et al (83) & 1390 & \multicolumn{2}{|r|}{ Shiraz } & Iran & Urban & 3000 & $\begin{array}{c}13 \text { to } 14 \\
\text { years }\end{array}$ & Girl/Boy & 11 \\
\hline Abbasi Ranjbar Z. (84) & 2004 & \multicolumn{2}{|r|}{ Rasht } & Iran & Urban & 6060 & $\begin{array}{l}6 \text { to } 14 \\
\text { years }\end{array}$ & Girl/Boy & 12 \\
\hline Karimi M. et al (42) & 2006 & \multicolumn{2}{|r|}{ Yazd } & Iran & Urban & 2740 & 6 to 7 years & Girl/Boy & 9 \\
\hline Sahebi L. et al (85) & 2011 & \multicolumn{2}{|r|}{ Tabriz } & Iran & Urban & 1508 & $\begin{array}{l}13 \text { to } 16 \\
\text { years }\end{array}$ & Girl/Boy & 6 \\
\hline Gharagozlou M. et al (86) & 2006 & \multicolumn{2}{|r|}{ Kashan } & Iran & Urban & 2533 & $\begin{array}{c}13 \text { to } 14 \\
\text { years }\end{array}$ & Girl/Boy & 11 \\
\hline Zohal M.A. et al (87) & 2004 & \multicolumn{2}{|r|}{ Qazvin } & Iran & Urban & 5068 & $\begin{array}{l}6 \text { to } 14 \\
\text { years }\end{array}$ & Girl/Boy & 12 \\
\hline Najafizadeh K. et al (88) & 2008 & & Rasht & Iran & Urban & 6074 & 6 to14years & Girl/Boy & 12 \\
\hline Gharagozlou M. et al (89) & 2002 & & Kashan & Iran & Urban & 3003 & 6 to 7 years & Girl/Boy & 10 \\
\hline Amra B. et al (90) & 2005 & & Isfahan & Iran & Urban & 2413 & 6 to14years & Girl/Boy & 8 \\
\hline Karimi M. et al (45) & 2006 & & Yazd & Iran & Urban & 3151 & $\begin{array}{l}13 \text { to } 14 \\
\text { years }\end{array}$ & Girl/Boy & 10 \\
\hline Hatami G. et al (91) & 2001 & & Bushehr & Iran & Urban & 2699 & $\begin{array}{l}13 \text { to } 14 \\
\text { years }\end{array}$ & Girl/Boy & 11 \\
\hline Golshan M. et al (92) & 1998 & & Isfahan & Iran & Urban & 3924 & $\begin{array}{l}10 \text { to } 17 \\
\text { years }\end{array}$ & Girl/Boy & 9 \\
\hline Al-Rawas O.A. et al (58) & 2009 & & Muscat,Sharqiah & Oman & Urban & 2441 & 10 years & Girl/Boy & 8 \\
\hline Golshan M.et al (29) & 2001 & & Isfahan & Iran & Urban & 3668 & $\begin{array}{l}15 \text { to } 18 \\
\text { years }\end{array}$ & Girl/Boy & 10 \\
\hline Hajavi et al (93) & 2011 & & Gonabad & Iran & $\begin{array}{c}\text { Urban / } \\
\text { rural }\end{array}$ & 1626 & $\begin{array}{c}12 \text { to } 18 \\
\text { years }\end{array}$ & Girl/Boy & 7 \\
\hline $\begin{array}{l}\text { Trend of } \\
\text { change }\end{array}$ & $\begin{array}{l}\text { alence of a } \\
\text { second stu }\end{array}$ & $\begin{array}{l}\text { thma in } \\
\%\end{array}$ & $\begin{array}{l}\text { The prevalence of asth } \\
\text { the First study } \%\end{array}$ & & $\begin{array}{c}\text { Interval of } 2 \\
\text { reviews }\end{array}$ & & group & Country & \\
\hline Increase & 11.2 & & 4.5 & & 2 Years & 6 to & 2 years & Palestine / & tallah \\
\hline Constant & 2.5 & & 2.6 & & 6 Years & $13 \mathrm{t}$ & 14 years & $\operatorname{Iran} / \mathrm{T}$ & \\
\hline Constant & 10.6 & & 10.5 & & 6 Years & & 7years & Oman $/ \mathrm{s}$ & \\
\hline Decrease & 19.8 & & 20.7 & & 6 Years & 13 & 14years & $\mathrm{Oman} / \mathrm{S}$ & \\
\hline Increase & 13.2 & & 10.9 & & 6 Years & 13 & 14years & Ira & \\
\hline Increase & 2 & & 1.4 & & 8 Years & 13 & 14years & $\operatorname{Iran} / \mathrm{T}$ & \\
\hline Increase & 7.1 & & 4.1 & & 6 Years & $6 \mathrm{t}$ & 7 years & $\operatorname{Iran} / \mathrm{I}$ & \\
\hline Increase & 4.5 & & 2.7 & & 6 Years & $13 \mathrm{t}$ & 14 years & $\operatorname{Iran} / \mathrm{I}$ & \\
\hline Decrease & Girls:1.2 & & Girls:1.5 & & 6 Years & & 7 years & $\operatorname{Iran} / \mathrm{T}$ & \\
\hline & Boys: 1.0 & & Boys: 1.9 & & & & & & \\
\hline
\end{tabular}

The quality score of each paper was assessed, and the most common limitations of the studies were: 1) not reporting the confidence interval of the prevalence, 2) including age groups not comply with ISAAC protocol and 3) the reported prevalence was not according to the defined age groups of ISAAC (Fig. 2).

During the period of 1996-2011, the prevalence of asthma in children of the Middle East was $7.57 \%$ $(95 \% \mathrm{Cl}=6.38-8.75)$. There was significant heterogeneity in the studies. $\left(\mathrm{I}^{2}=99 \% ; \mathrm{p}<0.001, \mathrm{df}=45\right.$ and $\mathrm{Q}=9006.7$ ) (Fig. 3).

The prevalence of asthma among girls, based on the random effect model, was $6.30 \%(95 \% \mathrm{Cl}=4.97$ $7.61)$ and among boys, it was $8.91 \%(95 \% \mathrm{Cl}=6.80$ 11.04). Prevalence of asthma in the 13-14 years age group (23 studies) was $7.53 \%(95 \% \mathrm{Cl}=5.78-9.29)$ based on the random effect model. The prevalence of asthma in the 6 to 7 years old group, was $7.43 \%$ $(95 \% \mathrm{Cl}=5.75-9.1)$ based on the random effect model. In 12 studies, the prevalence of asthma in the age group of 6 to 7 was $7.68 \%(95 \% \mathrm{Cl}=5.02-10.34)$ was higher than the age group of 13 to $14 ; 6.1 \%$ $(95 \% \mathrm{Cl}=4.41-6.91)$.

\section{Discussion}

Prevalence of asthma in the Middle Eastern children aged 13-14 years was $7.57 \%(95 \% \mathrm{Cl}$ : 6.38 $8.75)$. The minimum prevalence rate of asthma $(0.7 \%)$ was observed in Isfahan in Iran (29), and the highest $22.3 \%$ was reported from Bagdad in Iraq 


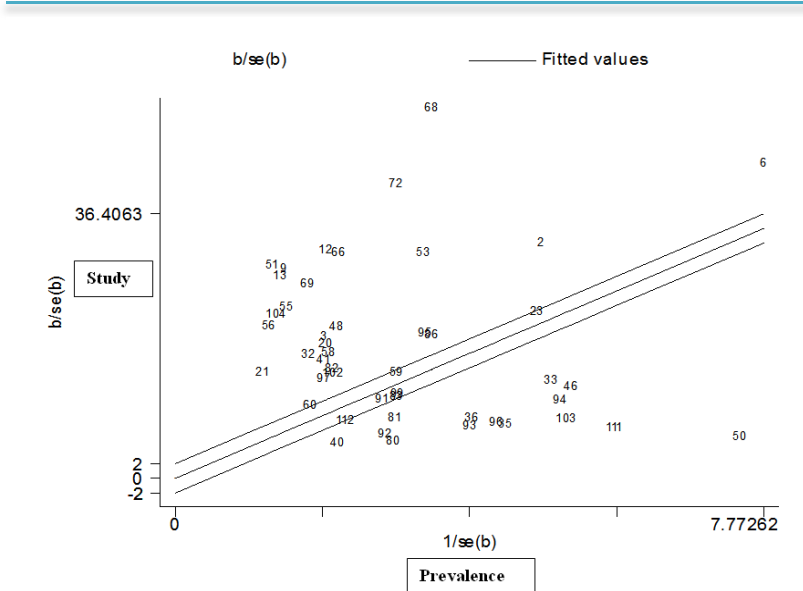

Fig. 2. Sensitivity analysis of the effect of excluded papers on the final estimate of asthma prevalence in children of the Middle East 1996-2011

(30).

Prevalence of asthma in the Middle East is lower than many developed countries such as the UK (25.9\%) (31), Spain (12.8\%) (32), Australia (31\%) (33), and also Turkey (17.8\%) (34). However, it is higher than some developing countries like Tibet area in China (1.1\%), (35) India (4.9\%) (36) and Taiwan (6\%) (37).

Studies in the Middle East also show that the prevalence of asthma is higher among younger boys. However, the difference decreases between the two sexes in early adolescence. In Japan prevalence of asthma was higher in boys (6\%) than girls (4\%) (38).
In Turkey, the prevalence of asthma in boys (19.4\%) is slightly higher than girls (16.2\%) (34) similar to Nigeria, South Korea, and India $(36,39,40)$.

The prevalence of asthma in countries around the world in the age group 6 to 7 years varies from 1.8\% in Lithuania to $27.4 \%$ in Costa Rica. In the age group 13 to 14 years the lowest prevalence rate reported from Albania $(2.6 \%)$ and the highest from Peru $(30.5 \%)$.

The prevalence of asthma is higher in older children, e.g. in Indonesia the prevalence of asthma among children 6-7 years is $5.3 \%$ and among children $13-14$ years is $7 \%$. This increase was reported from Germany ( $4.3 \%$ vs. $7.5 \%)$ and Singapore $(17 \%$ vs. 23.7) too. However, in some countries like Costa Rica the prevalence of asthma among children 6 to 7 years old $(27.4 \%)$ is slightly higher than the 13-14 years age group (20.8\%), the reported difference in other countries is limited to $1 \%(41)$.

In a systematic review, Pearce et al. reported that across 35 countries of the world, the prevalence of asthma in 21 countries $(60 \%)$ is higher in the older age group and in nine countries $(25.7 \%)$ is higher in the younger age group. It was reported in 10 countries $(25.7 \%)$ that the difference was insignificant, and in only 5 countries the prevalence of asthma was higher in the 6 to 7 years age group including; Iran and Oman (41). Overall, in the Middle East, the prevalence of asthma is higher in the 13-14 years

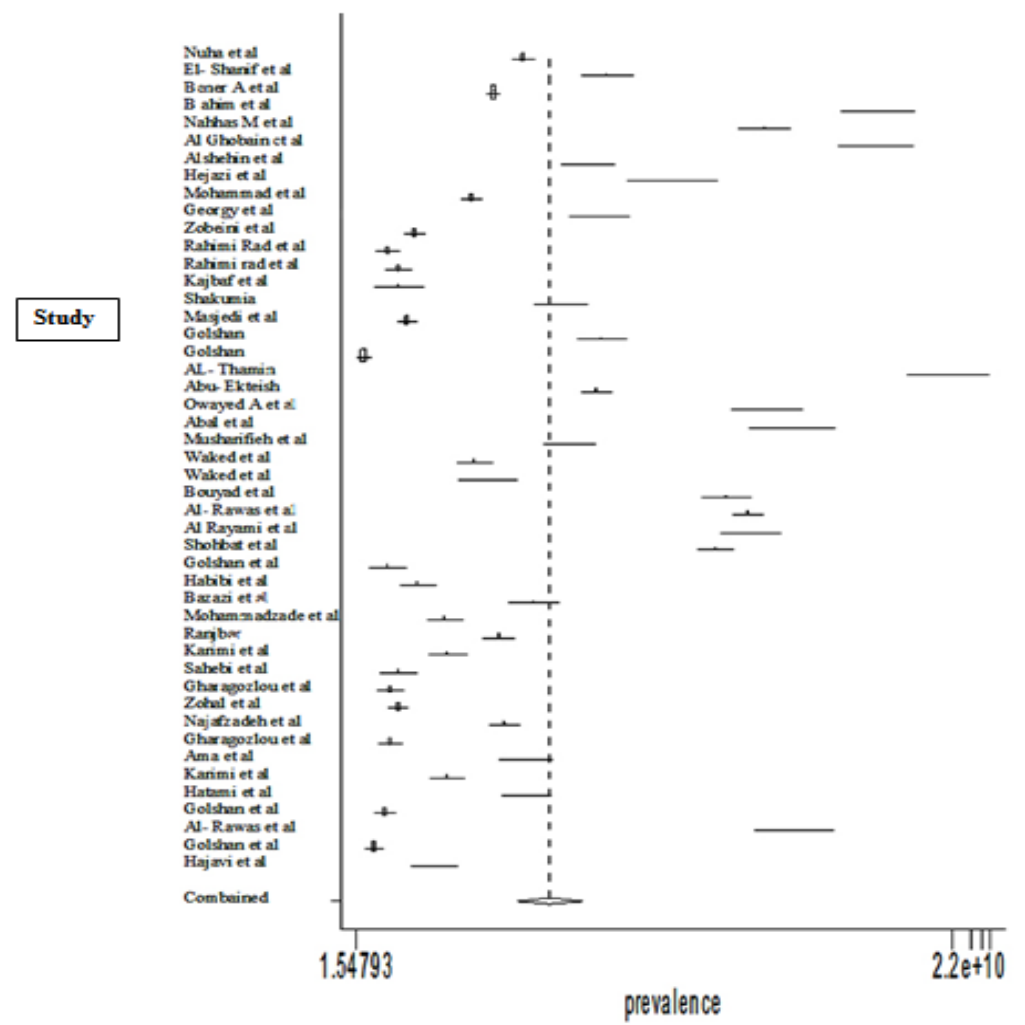

Fig. 3. Pool estimate of the prevalence of asthma in children of the Middle East 1996-2011 
age group.

This is the first systematic review of the prevalence of asthma in children of the Middle East. There are some limitations to this study. The heterogeneity across the papers was significant. This may be due to different age groups considered across the studies although they used the same ISAAC criteria. According to the meta-regression analysis, there was no significant relationship between the prevalence of asthma and other methodological factors. There are not enough longitudinal data on changes in the prevalence over time. So the prevalence studies should be repeated.

\section{Conclusion}

The prevalence of asthma in the Middle East is lower than most developed countries. However, there is not enough longitudinal data to estimate the trend over time. The prevalence studies of asthma in the Middle East have to be repeated every 5 years using standard criteria such as ISACC to assess the secular trends of the changes over time.

\section{Acknowledgments}

None.

\section{Conflict of Interest: None declared.}

\section{References}

1. Upton MN, McConnachie A, McSharry C, Hart CL, Smith $\mathrm{GD}$, Gillis $\mathrm{CR}$, et al. Intergenerational 20 year trends in the prevalence of asthma and hay fever in adults: the Midspan family study surveys of parents and offspring. Bmj 2000; 321(7253):88-92.

2. Yunginger JW, Reed CE, O'Connell EJ, Melton LJ, O'Fallon WM, Silverstein MD. A community-based study of the epidemiology of asthma: incidence rates, 1964-1983. American journal of respiratory and critical care medicine 1992; 146(4):888-94.

3. Masoli M, Fabian D, Holt S, Beasley R. The global burden of asthma: executive summary of the GINA Dissemination Committee report. Allergy 2004; 59(5):469-78.

4. Committee IS. Worldwide variations in the prevalence of asthma symptoms: the International Study of Asthma and Allergies in Childhood (ISAAC). The European respiratory journal: official journal of the European Society for Clinical Respiratory Physiology 1998;12(2):315-35.

5. Beasley R, Crane J, Lai CKW, Pearce N. Prevalence and etiology of asthma. Journal of allergy and clinical immunology 2000; 105(2):S466-S72.

6. Toelle BG, Ng K, Belousova E, Salome CM, Peat JK, Marks GB. Prevalence of asthma and allergy in schoolchildren in Belmont, Australia: three cross sectional surveys over 20 years. Bmj 2004; 328(7436):386-7.

7. Robertson CF, Roberts MF, Kappers JH. Asthma prevalence in Melbourne schoolchildren: have we reached the peak? Medical Journal of Australia 2004;180(6):273-6.

8. Mommers M, Gielkens-Sijstermans C, Swaen G, Van Schayck C. Trends in the prevalence of respiratory symptoms and treatment in Dutch children over a 12 year period: results of the fourth consecutive survey. Thorax 2005;60(2):97-9.

9. Lee SI, Shin MH, Lee HB, Lee JS, Son BK, Koh YY, et al. Prevalences of symptoms of asthma and other allergic diseases in Korean children: a nationwide questionnaire survey. Journal of Korean medical science 2001;16(2):155-64.

10. Kim YK, Kim SH, Tak YJ, Jee YK, Lee BJ, Park HW, et al. High prevalence of current asthma and active smoking effect among the elderly. Clinical \& Experimental Allergy 2002;32(12):1706-12.

11. Research/GlaxoSmithKline I. Asthma Insights and Reality in Asia Pacific (AIRIAP) Korea: Executive Summary 2002.

12. Mathers CD, Stein C, Ma Fat D, Rao Ch IM, Tomijima N. Global Burden of Disease 2000: Version 2 methods and results, Global Programme on Evidence for Health Policy Discussion Paper No. 50. World Health Organization [Sitio en Internet] 2002.

13. (KNSO) KNSO. News release: Summary report of the cause of death statistics in 2003. Available from: kosis.nso.go.kr/Magazine/YD/VD0002. xls [accessed: 3 Jan 2005].

14. Moin M, Aghamohammadi A, Gharavi MH, Ardestani A, Faghihimehr A, Kouhi A, et al. Risk factors leading to hospital admission in Iranian asthmatic children. International archives of allergy and immunology 2008;145(3):244-8.

15. Balkissoon R. Asthma overview. Primary Care: Clinics in Office Practice 2008;35(1):41-60.

16. Magnus P, Jaakkola JJK. Secular trend in the occurrence of asthma among children and young adults: critical appraisal of repeated cross sectional surveys. Bmj 1997;314(7097):1795.

17. Glassel A. Finding quality resources on the Internet: filtering and selecting for the Internet scout project. Amsterdam, the Netherlands: International Federation of Library Associations and Institutions 1998. [Cited 11 Oct 2004].

18. Loney PL, Chambers LW, Bennett KJ, Roberts JG, Stratford PW. Critical appraisal of the health research literature: prevalence or incidence of a health problem. Chronic Dis Can 1998; 19(4):170-6.

19. Al-Ghamdi B, Mahfouz A, Abdelmoneim I, Khan M, Daffallah A. Altitude and bronchial Asthma in south-western Saudi Arabia. Eastern Mediterranean health journal 2008;14:1723.

20. Alsowaidi S, Abdulle A, Bernsen R, Zuberbier T. Allergic rhinitis and asthma: a large cross-sectional study in the United Arab Emirates. International archives of allergy and immunology 2010;153(3):274-9.

21. Tootoonchi P. Prevalence of asthma, related symptoms and risk factors in children younger than 5 years. Acta medica Iranica 2004;42(6).

22. Naeimi A, Hadinia A, Karimi A. Asthma prevalence and associated factors in children under six years of the logistic regression models and probity. Armaqane danesh 2011;272:1681 .

23. Sobki SH, Zakzouk SM. Point prevalence of allergic rhinitis among Saudi children. Rhinology 2004;42(3):137-40.

24. Waked M, Salameh P. Risk factors for asthma and allergic diseases in school children across Lebanon. Journal of asthma and allergy 2008;2:1-7.

25. Mortazavimoqadam GH, Saadatjoo R. Prevalence of asthma symptoms among 13 to 14 year old students in Birjand. Zahedan Medical University 2004;6(3):9-15

26. Boskabady M, Karimian M. Prevalence of asthma symptoms among secondary school students in the city of Mashhad, north-east of Iran. Availabe at: http://www.ams.ac.ir/AIM/0034/ boskabady0034 html.

27. Behbehani NA, Abal A, Syabbalo NC, Abd Azeem A, Shareef E, Al-Momen J. Prevalence of asthma, allergic rhini- 
tis, and eczema in 13- to 14-year-old children in Kuwait: an ISAAC study. International Study of Asthma and Allergies in Childhood. Ann Allergy Asthma Immunol 2000; 85(1):58-63.

28. Bener A, Janahi I. Association between childhood atopic disease and parental atopic disease in a population with high consanguinity. Collegium antropologicum 2005;29(2):677-82.

29. Golshan M, Mohamad-Zadeh Z, Zahedi-Nejad N, RostamPoor B. Prevalence of asthma and related symptoms in primary school children of Isfahan, Iran, in 1998. Asian Pacific journal of allergy and immunology / launched by the Allergy and Immunology Society of Thailand 2001; 19(3):163-70.

30. Al-Thamiri D, Al-Kubaisy W, Ali SH. Asthma prevalence and severity among primary-school children in Baghdad. Eastern Mediterranean health journal 2005;11(1-2):79-86.

31. Anderson HR, Ruggles R, Strachan DP, Austin JB, Burr M, Jeffs $D$, et al. Trends in prevalence of symptoms of asthma, hay fever, and eczema in 12-14 year olds in the British Isles, 1995-2002: questionnaire survey. Bmj 2004;328(7447):10523.

32. García-Marcos L, Quirós AB, Hernández GG, GuillénGrima F, Díaz CG, Urena IC, et al. Stabilization of asthma prevalence among adolescents and increase among schoolchildren (ISAAC phases I and III) in Spain. Allergy 2004; 59(12):1301-7.

33. Toelle BG, Ng K, Belousova E, Salome CM, Peat JK, Marks GB. Prevalence of asthma and allergy in schoolchildren in Belmont, Australia: three cross sectional surveys over 20 years. Bmj 2004; 328(7436):386-7.

34. Ones U, Akcay A, Tamay Z, Guler N, Zencir M. Rising trend of asthma prevalence among Turkish schoolchildren (ISAAC phases I and III). Allergy 2006;61(12):1448-53.

35. Yangzong Y, Shi Z, Nafstad P, Håheim LL, Luobu O, Bjertness E. The prevalence of childhood asthma in China: a systematic review. BMC public health 2012;12(1):860.

36. Dhabadi B, Athavale A, Meundi A, Rekha R, Suruliraman $\mathrm{M}$, Shreeranga A, et al. Prevalence of asthma and associated factors among schoolchildren in rural South India. The International Journal of Tuberculosis and Lung Disease 2012;16(1):120-6.

37. Lee YL, Hwang BF, Lin YC, Guo YL. Time trend of asthma prevalence among school children in Taiwan: ISAAC phase I and III surveys. Pediatric allergy and immunology 2007;18(3):188-95.

38. Kusunoki T, Morimoto T, Nishikomori R, Yasumi T, Heike $\mathrm{T}$, Fujii $\mathrm{T}$, et al. Changing prevalence and severity of childhood allergic diseases in Kyoto, Japan, from 1996 to 2006. Allergology international: official journal of the Japanese Society of Allergology 2009;58(4):543-8.

39. Falade A, Olawuyi J, Osinusi K, Onadeko B. Prevalence and severity of symptoms of asthma, allergic rhinoconjunctivitis, and atopic eczema in 6-to 7-year-old Nigerian primary school children: the international study of asthma and allergies in childhood. Medical Principles and Practice 2004;13(1):20-5.

40. Hong S, Son DK, Lim WR, Kim SH, Kim H, Yum HY, et al. The prevalence of atopic dermatitis, asthma, and allergic rhinitis and the comorbidity of allergic diseases in children. Environmental Health and Toxicology 2012;27.

41. Pearce N, Aït-Khaled N, Beasley R, Mallol J, Keil U, Mitchell $\mathrm{E}$, et al. Worldwide trends in the prevalence of asthma symptoms: phase III of the International Study of Asthma and Allergies in Childhood (ISAAC). Thorax 2007;62(9):758-66.

42. Karimi M, Mirzaei M, Ahmadieh MH. Acetaminophen use and the symptoms of asthma, allergic rhinitis and eczema in children. Iranian journal of allergy, asthma, and immunology 2006; 5(2):63-7.

43. Karimi M, Mirzaei M, Baghiani Moghadam B, Fotouhi E, Zare Mehrjardi A. Pet exposure and the symptoms of asthma, allergic rhinitis and eczema in 6-7 years old children. Iranian journal of allergy, asthma, and immunology 2011;10(2):123-7.

44. Mirzaei M. Children exposed to secondhand smoke associated Yazdi and Prevalence of asthma and allergies. Hormozgan University of Medical 2007;1:2-11

45. Karimi M, Mirzaei M. Antibiotic Use and Symptoms of Asthma, Allergic Rhinitis and Eczema in Children. Iranian Journal of Pediatrics 2009; 19(2):141-6.

46. Karimi M, Ehrampoush M, Mirzaei M, Ahmadieh M. Type of fuel consumed and frequency of lorry passing associated with allergic rhinitis and asthma symptoms in children. Iranian Journal of Environmental Health Science \& Engineering $2005 ; 2(2)$.

47. Karimi M, Mirzaei M, Akhondzarini R. And the prevalence of asthma and allergies in children's food. Shahid Sadoughy University of medical 2010;19(1):35-44

48. Rahimi Rad MH, Hejazi ME. Agreement between written and video asthma symptoms questionnaires in school children in Urmia, Iran. Iranian journal of allergy, asthma, and immunology 2007; 6(1):21-5.

49. Mirsaid Ghazi B, Imamzadehgan R, Aghamohammadi A, Darakhshan Davari R, Rezaei N. Frequency of Allergic Rhinitis in School-age Children (7-18 Years) in Tehran. Iranian journal of allergy, asthma, and immunology 2003;2(4):181-4.

50. Al-Sahab B, Atoui M, Musharrafieh U, Zaitoun F, Ramadan F, Tamim H. Epidemiology of eczema among Lebanese adolescents. International journal of public health 2008;53(5):2607.

51. Al-Rawas OA, Al-Riyami BM, Al-Kindy H, Al-Maniri AA, Al-Riyami AA. Regional Variation in the Prevalence of Asthma Symptoms among Omani School Children: Comparisons from Two Nationwide Cross-sectional Surveys Six Years Apart. Sultan Qaboos University medical journal 2008;8(2):157-64.

52. The ISAAC Story. Available from: isaac.auckland.ac.nz/resources/tools.php.

53. El-Sharif N, Abdeen Z, Qasrawi R, Moens G, Nemery B. Asthma prevalence in children living in villages, cities and refugee camps in Palestine. The European respiratory journal: official journal of the European Society for Clinical Respiratory Physiology 2002;19(6):1026-34.

54. Nahhas M, Bhopal R, Anandan C, Elton R, Sheikh A. Prevalence of allergic disorders among primary school-aged children in Madinah, Saudi Arabia: two-stage cross-sectional survey. PloS one 2012;7(5):e36848.

55. Shohat T, Graif Y, Garty BZ, Livne I, Green MS. The child with asthma at school: results from a national asthma survey among schoolchildren in Israel. The Journal of adolescent health: official publication of the Society for Adolescent Medicine 2005;37(4):275-80.

56. Shohat T, Green MS, Davidson Y, Livne I, Tamir R, Garty BZ. Differences in the prevalence of asthma and current wheeze between Jews and Arabs: results from a national survey of schoolchildren in Israel. Annals of Allergy, Asthma \& Immunology 2002;89(4):386-92.

57. Mohammad Y, Tabbah K, Mohammad S, Yassine F, Clayton $\mathrm{T}$, Hassan M. International study of asthma and allergies in childhood: phase 3 in the Syrian Arab Republic. Eastern Mediterranean health journal 2010;16(7):710-6.

58. Al-Rawas OA, Al-Riyami BM, Al-Maniri AA, Al-Riyami AA. Trends in asthma prevalence and severity in Omani schoolchildren: comparison between ISAAC phases I and III. Respirology (Carlton, Vic) 2008;13(5):670-3.

59. Al-Riyami BM, Al-Rawas OA, Al-Riyami AA, Jasim LG, Mohammed AJ. A relatively high prevalence and severity of asthma, allergic rhinitis and atopic eczema in schoolchildren in the Sultanate of Oman. Respirology (Carlton, Vic) 
2003;8(1):69-76.

60. Ait-Khaled N, Odhiambo J, Pearce N, Adjoh K, Maesano I, Benhabyles B, et al. Prevalence of symptoms of asthma, rhinitis and eczema in 13-to 14-year-old children in Africa: the International Study of Asthma and Allergies in Childhood Phase III. Allergy 2007;62(3):247-58.

61. El-Sharif NA, Nemery B, Barghuthy F, Mortaja S, Qasrawi $\mathrm{R}$, Abdeen Z. Geographical variations of asthma and asthma symptoms among schoolchildren aged 5 to 8 years and 12 to 15 years in Palestine: the International Study of Asthma and Allergies in Childhood (ISAAC). Ann Allergy Asthma Immunol 2003;90(1):63-71.

62. Janahi IA, Bener A, Bush A. Prevalence of asthma among Qatari schoolchildren: International Study of Asthma and Allergies in Childhood, Qatar. Pediatric pulmonology 2006;41(1):80-6.

63. Al Ghobain MO, Al-Hajjaj MS, Al Moamary MS. Asthma prevalence among 16- to 18-year-old adolescents in Saudi Arabia using the ISAAC questionnaire. BMC Public Health 2012;12:239.

64. Alshehri MA, Abolfotouh MA, Sadeg A, Al Najjar YM, Asindi AA, Al Harthi AM, et al. Screening for asthma and associated risk factors among urban school boys in Abha city. Saudi medical journal 2000;21(11):1048-53.

65. Hijazi N, Abalkhail B, Seaton A. Asthma and respiratory symptoms in urban and rural Saudi Arabia. The European respiratory journal: official journal of the European Society for Clinical Respiratory Physiology 1998;12(1):41-4.

66. Mohammad Y, Tabbah K, Mohammad S, Yassine F, Clayton $\mathrm{T}$, Hassan M. International study of asthma and allergies in childhood: phase 3 in the Syrian Arab Republic. Eastern Mediterranean health journal 2010;16(7):710-6.

67. Georgy V, Fahim HI, El-Gaafary M, Walters S. Prevalence and socioeconomic associations of asthma and allergic rhinitis in northern [corrected] Africa. The European respiratory journal: official journal of the European Society for Clinical Respiratory Physiology 2006;28(4):756-62.

68. Zobeiri M. Prevalence, risk factors and severity of asthma symptoms in children of Kermanshah, IRAN: ISAAC phase I, II. Acta medica Iranica 2011;49(3):184-8.

69. Rahimi Rad MH, Hejazi ME, Behrouzian R. Asthma and other allergic diseases in 13-14-year-old schoolchildren in Urmia, Iran. Eastern Mediterranean health journal 2007;13(5):1005-16.

70. Kajbaf TZ, Asar S, Alipoor MR. Relationship between obesity and asthma symptoms among children in Ahvaz, Iran: a cross sectional study. Italian journal of pediatrics 2011;37:1.

71. Shakurnia AH, Assar S, Afra M, Latifi M. Prevalence of asthma among schoolchildren in Ahvaz, Islamic Republic of Iran. Eastern Mediterranean health journal 2010;16(6):651-6.

72. Masjedi MR, Fadaizadeh L, Najafizadeh K, Dokouhaki P. Prevalence and Severity of Asthma Symptoms in Children of Tehran- International Study of Asthma and Allergies in Childhood (ISAAC). Iranian journal of allergy, asthma, and immunology 2004;3(1):25-30.

73. Golshan M, Mohammad-Zadeh Z, Khanlar-Pour A, IranPour R. Prevalence of asthma and related symptoms in junior high school children in Isfahan, Iran. Monaldi archives for chest disease 2002;57(1):19-24.

74. Abu-Ekteish F, Otoom S, Shehabi I. Prevalence of asthma in Jordan: comparison between Bedouins and urban schoolchildren using the International Study of Asthma and Allergies in Childhood phase III protocol. Allergy and asthma proceedings: the official journal of regional and state allergy societies 2009;30(2):181-5.

75. Owayed A, Behbehani N, Al-Momen J. Changing prevalence of asthma and allergic diseases among Kuwaiti children. An ISAAC Study (Phase III). Medical principles and practice: international journal of the Kuwait University, Health Science Centre 2008;17(4):284-9.

76. Abal AT, Ayed A, Nair PC, Mosawi M, Behbehani N. Factors responsible for asthma and rhinitis among Kuwaiti schoolchildren. Medical principles and practice: international journal of the Kuwait University, Health Science Centre 2010;19(4):295-8.

77. Musharrafieh U, Al-Sahab B, Zaitoun F, El-Hajj MA, Ramadan F, Tamim H. Prevalence of asthma, allergic rhinitis and eczema among Lebanese adolescents. The Journal of asthma: official journal of the Association for the Care of Asthma. 2009;46(4):382-7.

78. Waked M, Salameh P. Asthma, allergic rhinitis and eczema in 13-14-year-old schoolchildren across Lebanon. Le Journal medical libanais The Lebanese medical journal 2006;54(4):181-90.

79. Bouayad Z, Aichane A, Afif A, Benouhoud N, Trombati N, Chan-Yeung M, et al. Prevalence and trend of self-reported asthma and other allergic disease symptoms in Morocco: ISAAC phase I and III. The international journal of tuberculosis and lung disease: the official journal of the International Union against Tuberculosis and Lung Disease 2006;10(4):3717.

80. Khorasani S, Janqorbani M, et al. The prevalence of asthma among school children in Kerman 1997. Kerman University of Medical Journal 2002; 9(4):93-184.

81. Bazzazi H, Gharagozlou M, Kassaiee M, Parsikia A, Zahmatkesh $\mathrm{H}$. The prevalence of asthma and allergic disorders among school children in Gorgan. Journal of research in medical sciences 2007;12(1):28-33.

82. Mohammadzadeh I, Ghafari J, Savadkoohi RB, Tamaddoni A, Dooki MRE, Navaei RA. The Prevalence of Asthma, Allergic Rhinitis and Eczema in North of Iran. Iranian Journal of Pediatrics 2008;18(2).

83. Jafar zadeh, Basiri F, et al. Prevalence of asthma and allergic diseases in Shiraz adolescents with ISSAC. Zahedan University of Medical Journal 2010;13(8):5-39

84. Abbasi Ranjbar Z. Prevalence of asthma symptoms in children. Gilan University of Medical Journal 2004;14(56)

85. Shabestari MS, Sahebi L. Prevalence of Asthma, Rhinitis Allergic and Eczema among Middle School Students in Tabriz (Northwestern of Iran). Pediatric Research 2011;70:5

86. Gharagozlou M, Khalili S, Hallajmofrad M, Mohammadzadeh R, Mousavi G, Golkari H. Gender similarity in low agreement between written and video ISAAC asthma questionnaires. Monaldi archives for chest disease 2006;65(4):1848.

87. Hashemi nasab R, Zohal M, et al. The prevalence of asthma among children in Qazvin. Qazvin University of Medical Journal 2006;1:2-9

88. Najafizadeh K, Fadaizadeh L, Salek S. Prevalence and severity of asthmatic symptoms in rasht students: A report from ISAAC study. Tanaffos 2008;7(1):40-6.

89. Garaguzlo M, KHalili S, et al. The frequency and severity of asthma, rhinitis and eczema in children aged 7-6 Kashan. TUMJ 2003;61(1)

90. Amra B, Rahmani A, Salimi S, Mohammadzadeh Z, Golshan M. Association between asthma and body mass index in children. Iranian Journal of Allergy, Asthma and Immunology. 2005;4(1).

91. Hatami G, Amirozedi A, et al. Prevalence and severity of asthma, allergic rhinitis and atopic eczema in 14-13 year old school students in Bushehr. Outhern Medical Journal Bushehr University of Medical Sciences and Health Services 
Prevalence of asthma in Middle Eastern children

2001;5(2):67-175.

92. olshan M, Khanlarpour A, et al. The prevalence of asthma in adolescents in secondary schools. Research in Medical Sciences $1999 ; 5(2): 67-175$

93. Hajavi J, Tolideei H, et al. Does the prevalence of allergic disorders in children are different underlying urban and rural? Journal of Ofoqe Danesh 2012;18(2):6-21. 